\title{
REALISASI BENTUK TINDAK TUTUR DIREKTIF GURU BAHASA INDONESIA DALAM PROSES PEMBELAJARAN
}

\author{
Dede $^{1}$, Muhammad Suryadi ${ }^{2}$ \\ Universitas Diponegoro Semarang ${ }^{1,2}$ \\ dedehalimah450@gmail.com $^{1}$
}

Submit, 23-11-2019 Accepted, 25-12-2019 Publish, 25-12-2019

\begin{abstract}
ABSTRAK
Tujuan penelitian ini untuk mengetahui bentuk tindak tutur direktif guru bahasa Indonesia dalam proses pembelajaran. Dalam penelitian ini data primer dikumpulkan oleh peneliti secara langsung yaitu berupa tuturan-tuturan beserta konteksnya pada proses pembelajaran bahasa Indonesia yang menggandung tindak tutur direktif. Ada tiga tahapan dalam penelitian ini, yaitu penyediaan data, analisis data dan penyajian hasil analisis data. Hasil penelitian, pada realisasinya, pemakaian tuturan tetap digolongkan ke dalam tuturan direktif meskipun dalam penyampaiannya dengan menggunakan modus yang berbeda dan tidak sesuai dengan yang dituturkan, yaitu dengan modus imperatif, deklaratif, dan interogatif. Penggunaan tuturan perintah merupakan bentuk tuturan direktif yang dominan digunakan oleh pengajar pada saat pembelajaran. Simpulan, tindak tutur direktif guru pada proses pembelajaran Bahasa Indonesia secara umum memilki bentuk yang bervariasi, tuturan yang mengandung tuturan direktif cenderung ditemukan saat guru menjelaskan materi, dan pada saat guru memberikan tugas.
\end{abstract}

Kata Kunci: Tindak Tutur, Direktif, Pembelajaran Bahasa Indonesia

\begin{abstract}
The purpose of this study was to determine the form of directive speech acts of Indonesian language teachers in the learning process. In this study primary data were collected directly by the researcher in the form of utterances and their context in the Indonesian language learning process that contained directive speech acts. There are three stages in this research, namely the provision of data, data analysis and presentation of data analysis results. The results of the study, in its realization, the use of utterances are still classified as directive utterances even though they are delivered using different modes and are not in accordance with what is said, namely the imperative, declarative, and interrogative modes. The use of command speech is a form of directive speech that is predominantly used by instructors during learning. In conclusion, the directive speech acts of teachers in the Indonesian learning process generally have varied forms, speech containing directive speech tends to be found when the teacher explains the material, and when the teacher gives an assignment.
\end{abstract}

Keywords: Speech Acts, Directive, Indonesian Language Learning 


\section{PENDAHULUAN}

Aktivitas yang memakai bahasa sebagai media untuk menyampaikan ide, sarana, atau pendapat dan perasaa yang diujarkan secara lisan dinamakan tindak tutur. Tindak tutur dikaji secara mendalam dalam telaah pragmatik. Saat seseorang mengujarkan sebuah tuturan tentu saja tidak terlepas dari maksud dan makna untuk meminta melakukan suatu tindakan. Interaksi linguistik yang terjadi dalam suatu bentuk ujaran yang melingkupi ekspresi situasi psikologis dan tindak sosial. Dengan demikian tindak tutur lebih mempertunjukan pada makna atau tujuan tindakan dalam suatu tuturan. Misalnya pada proses pembelajaran Bahasa Indonesia didalam kelas, di mana ada interaksi antara guru dan siswa serta alat komunikasinya yaitu bahasa. Istilah tindak tutur pertama kali dikenalkan oleh Austin (1962), berpendapat bahwa ketika seseorang menuturkan sebuah kalimat sebenarnya seseorang tersebut juga melakukan tindakan melalui kalimat tersebut, atau bisa dikatakan bahwa tindak tutur adalah suatu tindakan yang dilakukan berdasarkan sebuah tuturan.

Implikasi dari sebuah tuturan bisa memicu berbagai tindak tutur, pada dasarnya tindak tutur (speech act) merupakan aspek pragmatik yang melibatkan dua pihak yaitu pembicara dan pendengar atau penulis dan pembaca. Dalam melaksanakan tugas pokoknya seorang guru tidak terlepas dari upaya membimbing dan mengarahkan siswanya agar mampu menggunakan bahasa indonesia yang baik dan benar berdasarkan konteksnya.Tindak tutur direktif merupakan tindak tutur yang memiliki fungsi memerintah atau menyuruh lawan tutur melakukan tindakan berdasarkan yang dituturkan.

Tindak tutur ini dapat disampaikan dengan berbagai macam cara berdasarkan konteks yang sedang terjadi. Peristiwa tutur merupakan situasi yang menggambarkan bagaimana tuturan tersebut dituturkan. Pada saat seseorang berinteraksi dengan lawan tutur, maka akan berpotensi terjadi hal-hal yang membuat lawan tutur merasa dirugikan atau menyinggung perasaan lawan tutur, sehingga tindak tutur direktif yang mengindikasikan tuturan perintah atau imperatif di sini tidak dapat dihindarkan dalam sebuah tindak komunikasi. Setiap orang memiliki cara yang berbeda untuk menunjukkan hormat dan penghormatan, menyuruh, meminta maaf, menghindari dan bahkan meminimalkan paksaan terhadap lawan tutur. 
Pembahasan dan pengkajian mengenai tindak tutur direktif ini tidak lepas dari penelitian-penelitian yang sudah dilakukan sebelumnya. Hasil penelitian Suseno (2012) mengenai tidak tutur direktif yang berjenis permintaan, perintah, pesan, nasehat yang dilakukan secara langsung dan tidak langsung pada proses belajar anak usia dua tahun yang disinkronisasikan dengan ketrampilan pengguanaan bahasa yang sesuai dengan perkembangan anak. Peneltian selanjutnya Yuliana et.al (2013) juga meneliti tindak tutur direktif pada kegiatan belajar mengajar yang dianalisis dengan metode interaktif. Kemudian Sari (2016) membahas tentang fungsi asertif dari tuturan yang dihubungakan dengan indikator pencapaian kompetensi yang tercantm pada silabus kelas delapan mata pelajaran Bahasa Indonesia.

Hasil penelitian Hasanah (2017) berhubungan dengan fungsi aksi tutur ilokusi asertif, direktif, komisif, ekspresif, dan deklaratif yang dikaitakan dengan skill berbicara yang ada dalam mata pelajaran Bahasa Indonesia di SMP. Pada penelitian ini di temukan bahwa skill yang paling jarang ditemukan adalah aksi tutur model komisif. Penelitian sebelumnya membahas tenang tindak tutur direktif di berbagai sekolah dibawah sekolah umum. Namun pada penelitian ini difokuskan pada tindak tutur direktif pada guru bahasa Indonesia dalam proses pembelajaran di Madrasah Tsanawi (MTs) Negeri Demak yang merupakan satu-satunya Madrasah Negeri di Kecamatan Gajah. Madrasah ini menjadi acuan bagi Madrasah swasta yang berada di sekitarnya.

\section{METODE PENELITIAN}

Dalam penelitian ini data primer dikumpulkan oleh peneliti secara langsung yaitu berupa tuturan-tuturan beserta konteksnya pada proses pembelajaran bahasa Indonesia yang menggandung tindak tutur direktif. Ada tiga tahapan dalam penelitian ini, yaitu penyediaan data, analisis data dan penyajian hasil analisis data. Tahap penyediaan data yaitu dilakukan dengan menggunakan metode observasi. Metode observasi yang digunakan dalam penelitian ini adalah teknik sadap dengan teknik lanjutan simak bebas libat cakap (SLBC). Sedangkan metode cakap dengan teknik catat dan teknik rekam. Setelah data diperoleh berdasarkan metode pengumpulan data, maka tahap penelitian selanjutnya adalah tahapan menganalisis data. Dalam tahap analisis data ini peneliti menggunakan metode padan pragmatis. Metode padan pragmatis yaitu merupakan metode analisis yang digunakan untuk memaparkan maksud dari sebuah 
tuturan yang diungkapkan baik secara eksplisit maupun implisit. Kemudian agar penelitian ini dapat menjawab rumusan masalah yang ada yaitu peneliti akan menjelaskan realisasi tinda tutur direktif yang digunakan oleh pengajar dalam pembelajaran di di Madrasah Tsanawiyah Negeri 4 Demak. Tahap akhir setelah selesai menganalisis data adalah tahapan penyajian analisis data yaitu sebuah paparan mengenai realisasi tindak tutur direktif yang disajikan secara informal.

\section{HASIL PENELITIAN}

Hasil analisis data menunjukkan bahwa tindak tutur direktif yang digunakan oleh pengajar bahasa Indonesia memiliki fungsi tuturan dengan indikator meminta, mengajak, menasehati, memerintah, dan melarang. Tuturan direktif yang digunakan juga terdiri dari tuturan langsung maupun tidak langsung. Penggunaan indikator tindak tutur direktif tersebut dapat dilihat pada data tabel berikut ini.

Tabel 1

Frekuensi Kemunculan Indikator Tuturan Direktif

\begin{tabular}{lcc}
\hline Fungsi tuturan/ Indikator & $\begin{array}{c}\text { Frekuensi Kemunculan } \\
\text { Data }\end{array}$ & Persentase \\
\hline Meminta & 24 & $35 \%$ \\
Mengajak & 2 & $3 \%$ \\
Menasihati & 4 & $6 \%$ \\
Memerintah & 27 & $40 \%$ \\
Melarang & 11 & $16 \%$ \\
Total & 68 & $100 \%$ \\
\hline
\end{tabular}

Data pada tabel tersebut menunjukkan bahwa tuturan direktif yang digunakan oleh pengajar bahasa Indonesia di MTs Negeri 4 Demak berjumlah 68 data. Tindak tutur direktif yang digunakan pengajar cenderung memiliki fungsi tuturan memerintah yaitu sebanyak 40\%, tuturan direktif dominan kedua yang digunakan oleh pengajar yaitu dengan indikator meminta dengan persentase $35 \%$, dan tuturan direktif dengan indikator melarang sebanyak 11\%. Sedangkan fungsi tuturan dengan indikator mengajak adalah bentuk tuturan yang tidak banyak digunakan oleh pengajar karena dibuktikan dengan jumlah kemunculan data yang sangat sedikit yaitu dengan persentase 3\%. Berdasarkan hasil penelitian, bentuk memerintah merupakan tuturan yang seringkali digunakan oleh pengajar, sehingga hal ini membuat guru seolah-olah menuntut siswa agar melakukan tindakan sesuai dengan yang dituturkan. Dengan 
demikian, perlu adanya penggunaan tuturan direktif oleh pengajar dalam pembelajaran bahasa Indonesia di MTs Negeri 4 Demak didominasi oleh tuturan menyuruh karena pengajar memiliki hubungan vertikal dengan siswa. Oleh karena itu, biasanya tuturan guru cenderung lugas dan bersifat menyuruh yang ditujukan kepada siswa agar para siswa melakukan tindakan berdasarkan apa yang dituturkan. Contoh tuturan guru kepada siswa yang menggunakan beberapa indikator tersebut adalah sebagai berikut.

Tabel 2

Realisasi Indikator Pada Tuturan Direktif

\begin{tabular}{|c|c|c|c|c|}
\hline Data & Konteks Tuturan & Partisipan & Tuturan & Indikator \\
\hline 1 & $\begin{array}{l}\text { Pada akhir kegiatan belajar } \\
\text { mengajar guru meminta } \\
\text { siswa untuk menumpuk } \\
\text { buku paket Bahasa } \\
\text { Indonesia dan meminta salah } \\
\text { satu siswa membawa ke } \\
\text { kantor guru. }\end{array}$ & Guru : & $\begin{array}{l}\text { " Tolong buku paketnya ditumpuk } \\
\text { jadi satu, mas eko nanti bawa ke } \\
\text { kantor ya." } \\
\text { (mulai menumpuk buku dan ditaruh } \\
\text { di meja urutan depan) }\end{array}$ & Meminta \\
\hline 2 & $\begin{array}{l}\text { Pembelajaran berakhir dan } \\
\text { guru myimpulkan materi dan } \\
\text { mengajak siswa bekenaan } \\
\text { dengan materi yang } \\
\text { disampaikan. }\end{array}$ & Guru: & $\begin{array}{l}\text { "Untuk itu marilah anak-anak kita } \\
\text { jaga kebersihan lingkungn terutama } \\
\text { disekitar kita biar kejadian- } \\
\text { kejadian tadi tidak terjadi. Ibu rasa } \\
\text { cukup pertemuan untuk kali ini. } \\
\text { Terimakasih, jangan lupa belajar } \\
\text { assalammualaikum wr wb." }\end{array}$ & Mengajak \\
\hline & & Siswa : & "Waalaikumsalam, Wr. Wb." & \\
\hline 3 & $\begin{array}{l}\text { Di sela-sela menjelaskan } \\
\text { teks eksposisi yang berjudul } \\
\text { dampak kemajuan } \\
\text { tekhnologi, guru } \\
\text { mengutarakan nasihat yang } \\
\text { berkesinambungan dengan } \\
\text { materi. }\end{array}$ & Siswa : & $\begin{array}{l}\text { "Main gadget boleh, belajar jangan } \\
\text { dilupakan ya. Tentunya sebagai } \\
\text { pelajar tugas utama kamu ya... } \\
\text { "Belajar" (bersama-sama guru dan } \\
\text { siswa) }\end{array}$ & Menasihati \\
\hline 4 & $\begin{array}{l}\text { Awal kegiatan pembelajaran } \\
\text { guru menyuruh siswa } \\
\text { membuka buku paket yang } \\
\text { sesuai dengan materi yang } \\
\text { akan disampaikan. }\end{array}$ & Guru : & $\begin{array}{l}\text { "Bukunya dibuka!, halaman } 92 \\
\text { hari ini kita akan belajar tentang } \\
\text { bagaimana menemukan unsur-unsur } \\
\text { pembentuk puisi" } \\
\text { "nggih bu" (membuka buku paket) }\end{array}$ & Memerintah \\
\hline 5 & $\begin{array}{l}\text { Perbincangan antara guru } \\
\text { dan siswa pada suasana } \\
\text { kegiatan belajar mengajar, } \\
\text { guru melarang siswa } \\
\text { membawa lembar kerja } \\
\text { untuk dikerjakan dirumah } \\
\end{array}$ & Siswa : & $\begin{array}{l}\text { "Eh,. Jangan ni masih ada waktu } \\
\text { lima menit, ayo sebisanya!" }\end{array}$ & Melarang \\
\hline
\end{tabular}

Contoh data tuturan pada tabel tersebut terjadi pada saat proses belajarmengajar di ruang kelas. Berdasarkan konteks, tuturan data (1) terjadi pada saat peristiwa belajar-mengajar akan berakhir. Guru meminta semua siswa untuk menumpuk 
buku paket Bahasa Indonesia dan meminta salah satu siswa membawa buku-buku yang sudah ditumpuk ke ruang guru. Pada tuturan "tolong buku paketnya ditumpuk jadi satu, mas eko nanti bawa ke kantor ya" terdapat indikator meminta yang digunakan oleh guru kepada siswa terlihat pada penggunaan kata tolong. Tuturan tersebut menunjukkan adanya keadaan vertikal antara guru dan siswa yang didominasi oleh guru dalam kegiatan belajar-mengajar di kelas. Sehingga dalam hal ini guru memiliki power dalam menuturkan tuturan direktif meminta agar siswa melakukan hal yang dituturkan oleh guru tersebut.

Tuturan guru pada data (2) juga dituturkan pada saat pembelajaran akan berakhir dan guru myimpulkan materi dan mengajak siswa bekenaan dengan materi yang disampaikan. Penanda lingual yang mengindikasikan bahwa tuturan tersebut termasuk ke dalam tuturan direktif ajakan yaitu ditunjukkan dengan adanya indikator pada penggunaan kata marilah yang berarti memiliki maksud mengajak lawan tutur untuk melakukan sesuatu. Tuturan tersebut merupakan tindak tutur langsung karena adanya kesesuaian antara bentuk tuturan. dan fungsi ujaran.

Tuturan data (3) terjadi pada saat guru menjelaskan teks eksposisi berjudul dampak kemajuan teknologi, yang kemudian guru mengutarakan nasihat yang berkaitan dengan materi yang disampaikan. Penggunaan kata jangan pada tuturan guru data (3) termasuk dalam tuturan direktif nasihat bukan larangan karena dilihat dari konteksnya guru sedang tidak melarang namun memberi himbauan kepada para siswa agar tidak melupakan tugas utama sebagai seorang siswa yaitu belajar. Dalam menentukan atau menganalisis tuturan tentu tidak dapat dilepaskan dari konteks, dengan adanya konteks dalam peristiwa tutur maka akan dapat diketahui termasuk ke dalam tuturan direktif larangan atau nasihat. Berdasarkan konteks, tuturan guru pada data (3) termasuk ke dalam tuturan menasihati dengan penggunaan pemarkah verbal kata jangan.

Awal kegiatan pembelajaran guru menyuruh siswa membuka buku paket sesuai dengan materi yang akan di jelaskan. Tuturan data (4) "bukunya dibuka!...” dengan intonasi yang lantang dan cukup tinggi, guru bermaksud agar siswa segera mematuhi perintah yang dituturkan, yaitu membuka buku pelajaran. Dengan intonasi yang cukup tinggi tersebut membuat siswa memperhatikan tuturan pengajar dan segera memberi tanggapan dengan menuturkan kata "nggih bu" yang berarti 'iya bu' dan segera membuka buku pelajaran yang dimaksud penutur. Tuturan data (04) adalah tuturan 
direktif dengan modus imperatif yang dituturkan secara langsung tersebut memiliki makna menyuruh atau memerintah. Berdasarkan keseluruhan data yang ditemukan, tuturan direktif perintah adalah bentuk tuturan yang dominan digunakan oleh pengajar kepada siswa.

Data (5) dikatakan sebagai tuturan direktif dengan indikator larangan yang dituturkan dalam bentuk tuturan direktif langsung. Tuturan tersebut ditandai oleh pemarkah verbal larangan seperti kata jangan. Tuturan tersebut memiliki implikatur bahwa si penutur melarang siswa untuk membawa pulang tugas yang diberikan karena masih tersisa waktu lima menit lagi untuk mengerjakan. Tuturan tersebut merupakan tindak tutur langsung karena adanya kesesuaian antara fungsi ujaran dengan bentuk tuturan.

\section{PEMBAHASAN}

Berdasarkan realisasi tindak tutur yang digunakan pada pembelajaran Bahasa Indonesia di MTs Negeri 4 Demak, peneliti menemukan bahwa tindak tutur direktif dituturkan secara berbeda-beda. Dari hasil pengamatan, terdapat tiga modus bentuk tuturan tindak tutur direktif pada pembelajaran bahasa Indonesia yaitu tindak tutur bermodus imperatif, deklaratif, dan interogatif. Tindak tutur direktif bermodus imperatif yaitu berarti penutur mengharapkan lawan tutur melaksanakan tindakan sesuai dengan yang dituturkan oleh penutur.

Tindak tutur direktif bermodus imperatif pada penelitian ini ditemukan seperti tuturan menyuruh, meminta, melarang, ataupun tuturan ajakan. Salah satu contoh tindak tutur direktif bermodus imperatif adalah sebagai berikut.

Konteks : Tuturan guru yang ditujukan kepada siswa yang sudah mendapat buku tugas untuk segera menulis puisinya di buku tugas.

(6) Guru : Yang dah pegang bukunya bisa langsung mengerjakan, tulis puisinya!

$$
\text { Siswa : (Siswa mulai menulis puisi) }
$$

Berdasarkan tuturan (6), pemilihan tuturan direktif langsung digunakan oleh pengajar. Bentuk tuturan langsung yang digunakan oleh guru tersebut mempunyai maksud sesuai dengan tujuan utama kalimat atau sesuai dengan sturktur kalimat secara literal. Dalam data tersebut, guru menyuruh atau memerintah siswa agar segera melakukan tindakan seperti yang ia tuturkan yaitu menulis puisi. Tuturan kata “... tulis 
puisinya!" dengan suara yang sedikit meninggi dimaksudkan agar siswa sesegera mungkin menjalankan perintah yang sampaikan oleh penutur atau pengajar. Apa yang dimanifestasikan oleh guru adalah sebuah keyakinan bahwa tuturan tersebut merupakan sebuah kebenaran yang wajib dilakukan bagi siswa-siswinya.

Tindak tutur direktif dengan modus deklaratif berarti penutur mengungkapkan tuturan direktif dengan menggunakan kalimat deklaratif. Biasanya tuturan tersebut dituturkan dengan nada atau intonasi datar dan tidak membutuhkan jawaban. Contoh tindak tutur direktif bermodus deklaratif yaitu seperti pada data berikut ini.

Konteks : Tuturan guru yang ditunjukan kepada siswanya bahwasannya waktu untuk mereka berdiskusi tinggal satu menit lagi.

(7) Guru : "Satu menit lagi, satu menit lagi"

Siswa : (mengakhiri diskusinya)

Data (7) dapat kita kategorikan ke dalam tindak tutur direktif bermodus deklaratif. Hal tersebut dibuktikan dengan adanya tuturan "satu menit lagi" yang diulang menunjukkan kategori perintah dengan modus memberitahu atau memberikan pernyataan atau menggunakan bentuk kalimat deklaratif. Secara literal tuturan guru tersebut memiliki maksud memberikan informasi mengenai durasi waktu diskusi. Berdasarkan respon atau tanggapan lawan tutur terhadap tuturan tersebut, memperlihatkan bahwa tujuan atau kehendak yang ingin dicapai penutur yang tersirat dalam tuturannya dapat tercapai. Tuturan guru atau penutur memiliki tujuan agar siswa segera menyelesaikan diskusi mengingat durasi waktu hanya tinggal satu menit. Oleh karena itu, data (7) merupakan manifestasi contoh tuturan guru yang dikategorikan kedalam tindak tutur direktif perintah dengan modus deklaratif.

Tuturan direktif ketiga yang ditemukan dalam realisasi tuturan yang digunakan oleh guru dalam interaksi belajar-mengajar adalah tuturan direktif bermodus interogatif. Tuturan direktif bermodus interogatif yaitu memiliki maksud bahwa berarti penutur mengungkapkan tuturan direktif dengan menggunakan kalimat interogatif. Tuturan ini memiliki intonasi meninggi pada akhir kalimat. Berdasarkan hasil penelitian, ditemukan tindak tutur direktif perintah berbentuk pertanyaan dengan indikasi menyuruh, mengancam dan meminta. Untuk lebih jelasnya perhatikan contoh data dan analisis di bawah ini. 
Konteks : Tuturan yang berlangsung terjadi antara siswa dan guru bahasa Indonesia dengan topik pembicaraan mengenai iklan di koran. Ada salah satu siswa mengambil dua buah koran yang ada di meja.

(8) Guru : "Kenapa dua?"

Siswa : (meletakan satu koran yang dipegang )

Peristiwa tutur tersebut termasuk dalam tuturan direktif dengan bentuk kalimat interogatif. Penutur menggunakan modus interogatif dalam tuturan direktif yang ia tuturkan. Bentuk tuturan interogatif pada tuturan guru terlihat pada penggunaan penanda lingual berupa kata tanya kenapa dan diakhiri dengan intonasi meninggi yaitu bertanya. Namun, meskipun menggunakan struktur kalimat tanya sebenarnya maksud dari tuturan tersebut bertujuan untuk melarang. Pola ujaran direktif larangan pada umumnya ditandai dengan adanya piranti kebahasaan yang menampilkan penggunaan kata jangan yang memiliki maksud memperingatkan atau melarang. Namun pada data (8) dikategorikan ke dalam jenis tindak tutur direktif larangan dengan modus interogatif, karena semestinya kata tanya tersebut digunakan oleh penutur untuk menanyakan sebuah alasan lawan tutur melakukan suatu aktivitas atau kegiatan tertentu. Namun berdasarkan konteks data, kata kenapa memiliki fungsi melarang siswa untuk melakukan suatu tindakan, yaitu larangan mengambil dua koran oleh masing-masing siswa. Penutur dalam tuturan tersebut memiliki tujuan yang ingin dicapai yaitu melarang siswa untuk mengambil dua koran. Berlandaskan contoh peristiwa tutur data (8), penggunaan kata tanya kenapa memiliki fungsi yang berbeda dengan bentuk tuturan. Tujuan tuturan direktif melarang bermodus interogatif tersebut dapat dilihat dari respons atau tanggapan lawan tutur.

\section{SIMPULAN}

Tindak tutur direktif guru pada proses pembelajaran Bahasa Indonesia di MTs Negeri 4 Demak secara umum memilki bentuk yang bervariasi. Tuturan yang mengandung tuturan direktif cenderung ditemukan saat guru menjelaskan materi, dan pada saat guru memberikan tugas. Tuturan direktif yang digunakan oleh guru memiliki gaya penyampaian yang berbeda berdasarkan situasi dan konteks. 


\section{DAFTAR PUSTAKA}

Austin, J.L. (1962). How to do Thing with Word. New York: Oxford University Press Hasanah, U.,S. (2017). Tindak Tutur Guru dan Siswa Kelas VIII pada Pembelajaran Bahasa Indonesia dan Implikasinya dalam Pembelajaran Kemampuan Berbicara di Sekolah Menengah Pertama (SMP). Bandar Lampung: FKIP Universitas LampungSearle,

Sari, R.,R . (2016). Tindak Tutur Asertif pada Proses Pembelajaran Bahasa Indonesia di Kelas SMP Negeri 17 Pesawaran Tahun Pelajaran 2016/2017 dan Implikasinya dalam Pembelajaran Bahasa di SMP. Bandar lampung : FKIP Universitas Lampung.

Susaeno, Y. (2012). Tindak Tutur Direktif pada Anak Usia Dua Tahun dan dan implikasinya pada Pembelajaran Kemampuan Berbahasa di PAUD" pada http:// diglib.unila.ac.id.8448/diakses pada 18 Oktober 2018

Yuliana, R. (2013). Daya Pragmatik Tindak Tutur Guru dalam Pembelajaran Bahasa Indonesia Pada Siswa Sekolah Menengah Pertama. Surakarta: Universitas Sebelas Maret. 